\title{
PROSES PELIPUTAN BERITA “LINTAS PAGI” RRI SEMARANG DALAM PERSPEKTIF KOMUNIKASI ISLAMI
}

\author{
Ahdini Rizqi Ardani \\ Koperasi Swamitra Brebes \\ Email : halodiniardani@gmail.com
}

\begin{abstract}
$R$ adio is an auditive communication media with several characteristics, among them is a crosshairs and contain interference. Listening to radio programs can only be done once. One of the radio programs is news. Dissemination of information and news via radio can take place quickly and wider. Broadcast news on the radio must be true, once the news is wrong in broadcast it is not possible to repeat again. Because the listener may only hear the error, do not hear what is rectified. It may also be that the listener did not hear the error, so that the wrong message rectified is correct. In the context of Islamic communication spreading good, true, and honest news is a must. Islamic communication is a way of communicating that is Islamic, which is not contrary to the teachings of the Qur'an and Hadith.

This study aims to describe the news coverage process "Lintas Pagi" RRI Semarang in the perspective of islamic communication. This research is a descriptive qualitative research by using data analysis technique Miles and Huberman.

Based on research conducted on the news coverage of "Lintas Pagi" RRI Semarang, then obtained the result that the news coverage process "Lintas Pagi" RRI Semarang in the perspective of Islamic communication without realizing has applied the principles of Islamic communication. These principles are qawlan sadidan, qawlan baligha, qawlan karima, qawlan ma'rufan, qawlan layyina, and qawlan maisura.
\end{abstract}

Keywords: news coverage, morning news, islamic communication perspective

\begin{abstract}
ABSTRAK
$\mathrm{R}$ adio merupakan media komunikasi auditif dengan beberapa karakteristik, di antaranya adalah selintas dan mengandung gangguan. Mendengarkan program radio hanya dapat dilakukan sekali. Salah satu program radio adalah berita. Penyebaran informasi dan berita melalui radio dapat berlangsung cepat dan lebih luas. Menyiarkan berita di radio harus benar, sekali berita tersebut salah dalam menyiarkan tidak mungkin di ulang kembali. Karena pendengar mungkin hanya mendengar ralatnya saja, tidak mendengar apa yang diralat. Mungkin pula pendengar tidak mendengar ralatnya, sehingga berita salah yang diralat dianggapnya benar. Dalam konteks komunikasi islami menyebarkan berita yang baik, benar, dan jujur adalah sebuah keharusan. Komunikasi islami merupakan cara berkomunikasi yang bersifat islami, yang tidak bertentangan dengan ajaran Al-Qur'an dan Hadits.

Penelitian ini bertujuan untuk mendeskripsikan proses peliputan berita "Lintas Pagi" RRI Semarang dalam perspektif komunikasi islami. Penelitian ini merupakan jenis penelitian deskriptif kualitatif dengan menggunakan teknik analisis data Miles dan Huberman,

Berdasarkan penelitian yang dilakukan terhadap proses peliputan berita "Lintas Pagi" RRI Semarang, maka diperoleh hasil bahwa proses peliputan berita "Lintas Pagi" RRI Semarang dalam perspektif komunikasi islami tanpa di sadari telah menerapkan prinsip-prinsip komunikasi islami. Prinsip-prinsip ini yaitu qawlan sadidan, qawlan baligha, qawlan karima, qawlan ma'rufan, qawlan layyina, dan qawlan maisura.
\end{abstract}

Kata kunci : liputan berita, lintas pagi, perspektif komunikasi islami 


\section{PENDAHULUAN}

Radio adalah media komunikasi yang bersifat auditif (dengar) dengan penyajian berita yang mengandalkan sistem gelombang elektronik. Penyebaran informasi dan berita melalui radio dapat berlangsung cepat dan lebih luas. Beberapa keunggulan radio sebagai media massa, antara lain : Pertama, bersifat langsung karena penyusunan dan penyajian berita tanpa melalui proses yang rumit sehingga dapat disiarkan secara langsung dan cepat, Kedua, jangkauan luas karena didukung sistem gelombang suara sehingga informasi dapat menembus berbagai wilayah di dunia, Ketiga menarik karena bersifat lebih dinamis dengan dukungan unsur musik, kata-kata, efek suara, dan nilai aktualitas berita di radio lebih tinggi dibanding media massa lainnya (Yunus, 2010:31).

Radio mempunyai kecepatan lebih dibanding medium komunikasi lainnya dalam melayani materi informasi. Pemberitaan radio punya daya jangkau yang seketika. Dalam waktu sekejap, apa yang terjadi dilapangan dapat langsung di siarkan dan masyarakat bisa langsung menyimpulkan apa yang terjadi. Akibatnya fatal bila terjadi kesalahan pada pemberitaan radio. Maka, berita radio harus benar, karena sekali berita itu disiarkan, tidak mungkin diralat. Pendengar mungkin hanya mendengar ralatnya saja, tidak mendengar apa yang diralat. Mungkin pula ia tidak mendengar ralatnya, sehingga berita salah yang diralat dianggapnya benar (Effendy, 1990:143).

Atas dasar itu, penyajian berita jurnalistik harus memperhatikan sifat-sifat berita, seperti aktual, objektif, akurat, menarik, perhatian dan tanggung jawab. Seperti yang telah diterangkan dalam Peraturan Pemerintah Republik Indonesia
Nomor 11 Tahun 2005 Tentang Penyelenggaraan Penyiaran Lembaga Penyiaran Publik pasal 18 ayat 4(a) tentang penyelenggaraan penyiaran bagian isi siaran menjelaskan bahwa isi siaran RRI, TVRI, dan Lembaga Penyiaran Publik Lokal dilarang : Pertama bersifat fitnah, menghasut, menyesatkan dan/atau bohong. Kedua menonjolkan unsur kekerasan, cabul, perjudian, penyalahgunaan narkotika dan obat terlarang. Ketiga mempertentangkan suku, agama, ras dan antar golongan.

Secara Ideal dalam membuat sebuah berita, seorang reporter harus melakukan tiga langkah, yaitu : Pertama, melakukan observasi, yaitu seorang reporter datang ke tempat kejadian perkara. Kedua, melakukan wawancara yaitu wawancara dengan orang yang memiliki pengetahuan mengenai kejadian yang akan dijadikan sebuah berita. Ketiga, melakukan riset, yaitu melakukan telaah literatur seperti membuka file, kliping pustaka dan dokumen lain yang dapat memberi informasi sebagai referensi tambahan untuk memperkaya latar belakang pengetahuan atas pokok masalah yang akan ditulis. Jika seorang reporter hanya pergi ke tempat kejadian dan melakukan siaran pers (news releases) dan bahan tertulis lainnya (handout), lalu kembali ke kantor dan menulis laporannya itu bukan yang dimaksud dengan reporting. (Oramahi, 2003:58).

Pemanfaatan media radio untuk kepentingan siaran informasi dan berita juga dilakukan oleh Radio Republik Indonesian (RRI). RRI adalah satu-satunya stasiun radio yang dimiliki oleh Negara Kesatuan Republik Indonesia (NKRI). RRI merupakan radio yang mempunyai posisi yang strategis, sebab realitasnya RRI masih merupakan satu-satunya radio jaringan nasional dan mampu menjangkau hampir 
seluruh wilayah Indonesia. RRI tersebar di seluruh pelosok nusantara. Salah satu contohnya adalah RRI Semarang.

RRI Semarang mempunyai tiga Programa siaran, yaitu: Pertama Programa I yang menempati frekueksi gelombang FM 89.0 MHz dan AM $801 \mathrm{KHz}$, dengan daya jangkau Programa I meliputi Jawa Tengah dan sasaran segmen pendengar semua umur (umum), menyajikan siaran dalam bentuk berita, siaran pendidikan, kebudayaan dan juga hiburan, Kedua Programa II dengan frekuensi gelombang FM 95.3 MHz dengan daya jangkau Kota Semarang dan sekitarnya, sasaran pendengar Programa II adalah kaum muda dengan siaran lebih menonjolkan pada informasi dan musik, Ketiga Programa IV yang menempati gelombang FM 88.2 MHz memusatkan siaran pada acara mengenai kebudayaan Jawa Tengah dan pendidikan.

Proses peliputan berita di RRI belum menerapkan aturan ideal dalam meliput berita seperti yang telah dijelaskan diatas. Sehingga terjadi beberapa kesalahan. Kesalahan pertama yang terjadi pada 8 Desember 1952 yang dilakukan oleh RRI Jakarta. Terkait kabar wafatnya Sutan Syahrir yang pada saat itu menjabat sebagai Ketua Umum Partai Sosialis Indonesia dan negarawan kenamaan, yang juga pernah menjabat sebagai Perdana Menteri (Effendy, 1990:144).

Beberapa kesalahan penyiaran berita juga pernah terjadi di RRI Semarang, ketika tahun 2015 lalu Pertama, permasalahan yang terjadi adalah ketika salah penyebutan nama wakil ketua DPD Partai Gerindra Jawa Tengah, yang seharusnya bernama Sriyanto Saputro namun disebutkan dalam berita RRI Semarang adalah Ignatius Saputro, Kedua, salah penyebutan terkait berita dugaan korupsi yang dilakukan Dinas Sosial, dalam berita yang mengudara disebutkan terduga korupsi adalah Biro Sosial Jawa Tengah, padahal keduanya merupakan dua badan yang berbeda (wawancara dengan desk editor, Gautama Indra Praja, S.Sos pada tanggal 20 september 2016). Telah disebutkan diatas bahwa radio adalah media auditif yang mengandalkan sistem gelombang elektronik. Sehingga menyebaran berita dapat berlangsung cepat dan lebih luas. Apabila terdapat berita yang salah, sulit untuk melakukan ralat dan pendengar yang tidak mendengar ralatnya bisa menganggap benar yang telah diralat.

Agama Islam telah memberi peringatan dalam menyampaikan berita atau informasi hendaknya berhati-hati. Sehingga tidak terjadi kesalahan yang akhirnya membuat masyarakat salah dalam memahami berita. Sesuai dengan empat sifat nabi Muhammad SAW yaitu siddiq, amanah, tabligh, fathonah, seorang jurnalis muslim (komunikator) hendaknya memiliki keempat sifat nabi tersebut untuk bekal menjadi reporter. Karena dalam mempengaruhi masyarakat, media massa memegang peranan penting. Media massa pada umumnya terlibat dalam pembuatan wacana peristiwa-peristiwa yang terjadi dalam masyarakat.

Didalam hadits Nabi SAW disebutkan "Katakanlah apa yang benar sekalipun pahit", artinya bahwa media massa diharuskan menyiarkan berita yang jujur, teliti dan benar. Jika perspektif komunikasi islami dikaitkan dengan ajaran agama Islam (Al-Qur'an dan Hadits) maka salah satu sifat khas komunikasi islami adalah faktor etika. Di dalam komunikasi islami, pesan komunikasi tidak boleh merupakan sensasi, kebohongan, kefasikan, pelintiran kata-kata dan kebohongan publik. Pesan sangat erat kaitannya dengan komunikator, sehingga komunikator juga tidak boleh 
menggunakan simbol-simbol atau kata-kata yang kasar, yang menyinggung perasaan komunikan atau khalayak (Muis, 2001:72).

\section{RUMUSAN MASALAH}

Berdasarkan latar belakang di atas, maka yang menjadi rumusan masalah dalam penelitian ini adalah Bagaimana proses peliputan berita "Lintas Pagi" RRI Semarang dalam perspektif komunikasi islami ?

\section{PROSES PELIPUTAN}

Proses adalah urutan suatu peristiwa yang semakin lama semakin meningkat atau semakin menurun. Proses juga bisa diartikan sebagai rangkaian tindakan perbuatan atau pengolahan yang menghasilkan produk.

Dalam ilmu teknik, proses adalah urutan pelaksanaan atau kejadian yang saling terkait yang bersama-sama mengubah masukan menjadi keluaran. Proses dapat dilakukan oleh manusia, alam, atau mesin dengan menggunakan berbagai sumber daya (id.wikipedia.org, diakses pada 23 Januari 2018)

Peliputan adalah kegiatan jurnalistik berupa meliput langsung ke lapangan atau ke tempat kejadian perkara (Romli, 2005:7). Peliputan atau reporting berasal dari kata report yang artinya laporan, melaporkan (Djamaries, 2014:306). Sedangkan jurnalistik berasal dari kata journ, yang dalam bahasa Perancis, journ berarti catatan atau laporan harian. Secara sederhana jurnalistik diartikan sebagai kegiatan yang berhubungan dengan pencatatan atau pelaporan setiap hari (Sumadiria, 2014:2).

Peliputan berita diartikan sebagai proses pengumpulan data dan informasi dilapangan yang dilakukan jurnalis (wartawan atau reporter). Kegiatan jurnalistik juga dapat diartikan sebagai kegiatan mencari, mengumpulkan, mengolah, menyajikan dan menyebarluaskan berita melalui media kepada khalayak seluas-luasnya. Reportase adalah kegiatan meliput, mengumpulkan fakta-fakta tentang berbagai unsur berita, dari berbagai sumber/narasumber dan kemudian menuliskanya dalam bentuk berita.

Jadi yang dimaksud proses peliputan adalah rangkaian tindakan berupa mencari bahan yang akan dijadikan berita dengan cara meliput langsung ke tempat kejadian perkara dan menyebarluaskan berita kepada masyarakat. Jika ditinjau dari prosesnya, liputan jurnalistik dapat diklasifikasikan dalam 2 (dua) bentuk, yaitu (Yunus, 2010:56) :

\section{Liputan berita terduga}

Berita yang bermutu lahir dari proses perencanaan, liputan, dan penulisan berita yang baik pula. Liputan berita terduga selalu dimulai dari rencana liputan yang dihasilkan dari ruang redaksi yang ditandai dengan membuat rencana atau proyeksi berita tentang suatu masalah yang sedang terjadi dan layak menjadi berita. Liputan dilakukan mengacu pada TOR atau pointers yang disepakati redaksi. Layak atau tidaknya hasil liputan menjadi berita akan ditentukan dan diputuskan melalui sidang redaksi.

Untuk melakukan liputan berita terduga, ada beberapa hal yang perlu mendapat perhatian, yakni sebagai berikut (Yunus, 2010:56) :

1. Mempersiapkan rencana liputan yang optimal. Topik berita perlu digali secara produktif, kreatif dan kritis.

2. Liputan harus dapat dipertanggung jawabkan dan transparan. 
3. Memiliki catatan liputan yang jelas, akurat dan kontekstual.

Dalam strategi peliputan berita, liputan berita terduga termasuk dalam strategi news making. Secara harfiah news making adalah membuat berita. News making berarti mengangkat persoalan atau fenomena di tengah-tengah masyarakat menjadi berita. News making syarat akan perencanaan yang matang, ketika akan membuat sebuah peristiwa menjadi berita (Usman, 2009:94).

Cara melakukan perencanaan, ketika akan membuat sebuat peristiwa menjadi berita yaitu dengan melakukan agenda setting. Agenda setting merupakan pemikiran yang menyatakan bahwa media tidak mengatakan apa-apa yang orang pikirkan tetapi apa yang harus dipikirkan (Tamburaka, 2013:22).

Teori Penentuan Agenda atau dalam bahasa Inggris disebut Agenda Setting Theory adalah teori yang menyatakan bahwa media massa merupakan pusat penentuan kebenaran dengan kemampuan media massa untuk mentransfer dua elemen yaitu kesadaran dan informasi ke dalam agenda pubik, dengan mengarahkan kesadaran publik serta perhatiannya kepada isu-isu yang dianggap penting oleh media massa (Tamburaka, 2013:22).

Dua asumsi dasar yang paling mendasari tentang penentuan agenda adalah (Tamburaka, 2013:23) :

a) Masyarakat pers dan media massa tidak mencerminkan kenyataan, mereka menyaring dan membentuk isu.

b) Konsentrasi media massa hanya pada beberapa masalah masyarakat untuk ditayangkan sebagai isu-isu yang lebih penting daripada isu-isu lain.

Reporter yang mendapat tugas meliput berita terduga akan membuat berita berdasarkan peristiwa penting yang sengaja terjadi, direncanakan atau disengaja, contoh jumpa pers, unjuk rasa, kegiatan olah raga, kegiatan pemerintah dan peringatan harihari besar. Tetapi bisa saja meliput suatu peristiwa alam yang rutin terjadi semisal banjir, dengan harapan agar pemerintah setempat segera mengatasi persoalan di daerah yang terkena banjir.

\section{Liputan berita tak terduga}

Berbagai peristiwa dan masalah dapat terjadi kapan saja, tanpa diketahui sebelumnya atau tanpa diprediksi. Untuk tetap mendapatkan liputan berita dalam peristiwa yang tidak terduga dibutuhkan kemampuan jurnalis sebagai newshunter atau pemburu berita.

Oleh karena itu, untuk tetap mendapatkan liputan berita dalam peristiwa yang tidak terduga, setidaknya dibutuhkan kemampuan dasar yang harus dimiliki seorang jurnalis, di antaranya (Yunus, 2010:57) :
a) Kepekaan berita yang tajam.
b) Daya pendenger berita yang baik.
c) Pengembangan daya penciuman berita yang kuat.
d) Wawasan berita ke depan yang jelas dan luas.
e) Memiliki panca indera yang mahir untuk keperluan berita.
f) Memperkaya pengalaman berita dari lapangan.

Dalam strategi peliputan berita, liputan berita tak terduga termasuk dalam strategi news gathering. News gathering artinya mengumpulkan berita atau sederhananya adalah meliput suatu peristiwa. News gathering tidak membutuhkan perencanaan (Usman, 2009:94). Reporter hanya mengandalkan peristiwa yang tak teragendakan, berasal dari peristiwa yang tiba-tiba terjadi. Berita yang termasuk 
dalam jenis ini adalah berita kecelakaan, bencana alam, kebakaran, kriminalitas dan lain sebagainnya. Meliput berita tak terduga membutuhkan jaringan yang luas dan sumber-sumber informasi, seperti kepolisian, pemadam kebakaran, serta masyarakat luas.

Dengan kemampuan dasar yang dimiliki reporter, proses peliputan berita, baik yang terjadi secara terduga maupun yang tak terduga dapat diperoleh dengan optimal. Mengingat masing-masing memiliki kekurangan dan kelebihan, dan seorang reporter yang profesional harus dapat meliput segala jenis berita yang ditugaskan padanya.

\section{PERSPEKTIF KOMUNIKASI ISLAMI}

Menurut A. Muis dalam bukunya Komunikasi Islami memaparkan bahwa semua macam komunikasi Islam pada dasarnya tidak berbeda dengan komunikasi non-Islam dalam hal model, proses dan efeknya, tetapi yang membedakannya lebih kepada landasan filosofisnya. Landasan filosofis komunikasi Islam ialah Al-Qur'an dan Hadis Nabi. Jadi komunikasi Islam adalah proses penyampaian pesan antar manusia didasarkan pada ajaran agama Islam yang terkandung dalam al-Qur'an dan Hadis (Muis, 2001:34).

Isi perintah dan larangan sama atau serupa antara keduanya. Ihwal yang membedakan keduanya adalah sanksi dan pahalanya. Komunikasi umum (non-Islam) memang mementingkan etika, tetapi sanksi atas pelanggaran komunikator terhadap etika komunikasi hanya berlaku di dunia. Sedangkan sanksi atas pelanggaran terhadap etika komunikasi Islam berlaku sampai akhirat. Ada hukuman akhirat dan hukuman di alam kubur atau di alam barzah. Para pelanggar terancam sanksi yang pedih di akhirat (neraka) (Muis, 2001:34).

\section{Pengertian Perspektif Komunikasi \\ Islami}

Perspektif adalah cara melukiskan suatu benda pada permukaan, yang mendatar sebagaimana yang terlihat oleh mata dengan tiga dimensi (panjang, lebar dan tinggi). Perspektif juga bisa diartikan sebagai sudut pandang (kbbi.web.id, diakses pada 18 Januari 2018).

Komunikasi islami adalah proses penyampaian pesan antara manusia yang didasarkan pada ajaran Islam. Pengertian itu menunjukkan, bahwa komunikasi islami adalah cara berkomunikasi yang bersifat islami (tidak bertentangan dengan ajaran Islam). Dengan demikian pada akhirnya terjadi juga konveregensi (pertemuan) antara pengertian komunikasi Islam dengan komunikasi islami. Boleh dikatakan, komunikasi islami adalah implementasi (cara melaksanakan) komunikasi Islam (Muis, 2001:66).

Sehingga dapat di tarik kesimpulan bahwa perspektif komunikasi islami adalah sudut pandang atau cara pandang mengenai cara berkomunikasi yang bersifat islami, tidak bertentangan dengan ajaran Islam. Persepektif komunikasi islami adalah bagian dari perspektif komunikasi manusia (human communication) pada umumnya (Muis, 2001:34).

Pesan komunikasi islami bersumber dari Al-Qur'an dan Hadits Nabi. Tentulah pesan yang bersifat imperatif atau wajib hukumnya untuk dilaksanakan karena merupakan pesan kebenaran berdasarkan firman Allah SWT dan Hadits Nabi. Pesan tidak boleh merupakan sensasi, kebohongan, kefasikan, pelintiran kata-kata dan kebohongan publik. Dengan demikian proses komunikasi islami harus terikat pada 
norma-norma etika agama Islam (Muis, 2001:70).

Jika perspektif komunikasi islami dikaitkan dengan ajaran agama Islam (AlQur'an dan Hadits) maka salah satu sifat khas komunikasi islami adalah faktor etika. Komunikasi islami memiliki perbedaan dengan komunikasi non-islam. Perbedaan itu lebih kepada isi pesan (content) yang harus terikat pada perintah agama. Dengan sendirinya pula unsur pesan(content) mengikat unsur komunikator. Artinya, komunikator harus menjunjung tinggi etika. Komunikator harus memiliki nilai-nilai etika yang tinggi dalam menyampaikan pesan. Komunikator tidak boleh menggunakan simbol-simbol atau kata-kata yang kasar, yang menyinggung perasaan komunikan atau khalayak (Muis, 2001:72).

\section{Prinsip Komunikasi Islami}

Telah dipaparkan oleh Jalaluddin Rakhmat dalam bukunya Islam Aktual : Refleksi Sosial Seorang Cendikiawan Muslim, ada enam prinsip komunikasi Islami (Rakhmat, 1994:77-87) :

a) Qawlan Sadidan (perkataan yang benar)

Arti dari qawlan sadidan adalah ucapan yang jujur, lurus, tidak bohong, tidak berbelit-belit. Dapat diwujudkan dengan manjaga lisan. Jika dikaitkan dengan komunikasi, seorang komunikator dalam menyampaikan pesannya, berupa pesan yang jujur dan tidak melakukan kebohongan.

Allah memerintahkan qawlan sadidan sesudah taqwa. Hal tersebut dalam FirmanNya Q.S. Al-Ahzaab: 70

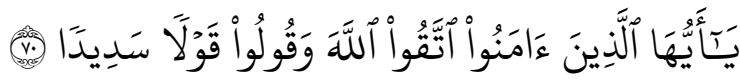

Artinya: "Wahai orang-orang yang beriman! Bertakwalah kamu kepada Allah dan ucapkanlah perkataan yang benar" (Departemen Agama RI, 2013:467).

Al-Qur'an menyatakan bahwa berbicara yang benar, adalah prasyarat untuk kebenaran (kebaikan, kemaslahatan) amal. Bila ingin memperbaiki masyarakat, maka harus menyebarkan pesan yang benar. Dengan kata lain, masyarakat menjadi rusak bila isi pesan komunikasi tidak benar.

b) Qawlan Baligha (efektif, tepat sasaran)

Kata "baligh" dalam bahasa arab artinya sampai, mengenai sasaran atau mencapai tujuan. Apabila dikaitkan dengan qawl (ucapan atau komunikasi), "baligh" berarti fasih, jelas maknanya, terang, tepat mengungkapkan apa yang dikehendaki. Oleh karena itu prinsip qawlan baligha dapat diterjemahkan sebagai prinsip komunikasi yang efektif.

Secara terperinci, ungkapan qawlan baligha dapat dilihat dalam Q.S.

An-Nisaa: 63

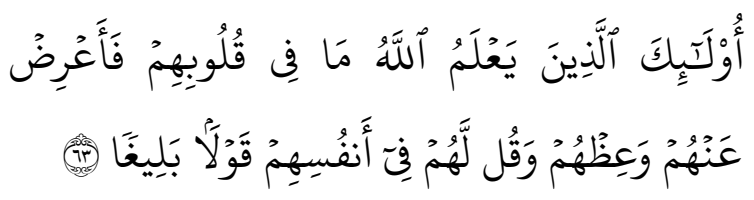

Artinya: "Mereka itu adalah orangorang yang (sesunguhnya) Allah mengetahui apa yang ada di dalam hatinya. Karena itu berpalinglah kamu dari mereka, dan berilah mereka nasihat, dan katakanlah kepada mereka perkataan yang membekas pada jiwanya" (Departemen Agama RI, 2013:88)

Bila qawlan baligha dikaitkan dengan komunikasi, artinya komunikator menyentuh khalayaknya pada hati dan otaknya sekaligus. Jika dicermati dapat disimpulkan kata qawlan baligha ialah menggunakan kata-kata yang efektif, tepat sasaran, komunikatif, mudah dimengerti, langsung ke pokok masalah (straight to the 
point). Agar komunikasi tepat sasaran, gaya bicara dan pesan yang disampaikan hendaklah disesuaikan dengan kadar intelektualitas komunikan dan menggunakan bahasa yang dimengerti oleh mereka.

c) Qawlan Karima (perkataan yang mulia)

Perkataan yang mulia, dibarengi dengan rasa hormat dan mengagungkan, enak didengar, lemah-lembut, dan bertata krama. Jika dikaji lebih jauh, komunikasi islami dengan menggunakan qawlan karima lebih ke sasaran dengan tingkatan umurnya lebih tua. Sehingga, pendekatan yang digunakan lebih pada pendekatan yang sifatnya pada sesuatu yang santun, lembut, dengan tingkatan dan sopan santun yang diutamakan. Dalam artian, memberikan penghormatan dan tidak menggurui dan retorika yang berapi-api.

Terkait dengan hal tersebut, ungkapan qawlan karima ini terdapat dalam Q.S. AlIsraa: 23

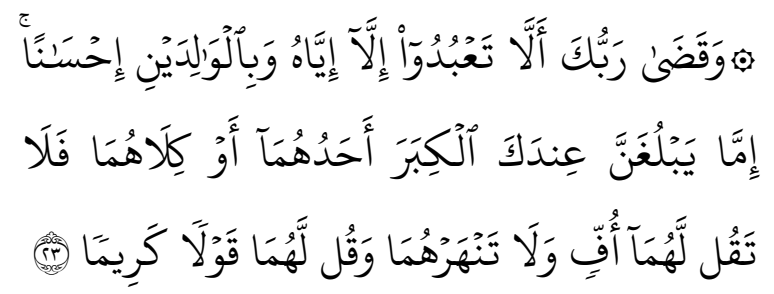

Artinya: "Dan Tuhanmu telah memerintahkan agar kamu jangan menyembah selain DIA dan hendaklah berbuat baik kepada ibu-bapak. Jika salah seorang diantara keduanya atau keduaduanya sampai berusia lanjut dalam pemeliharaanmu, maka sekali-kali janganlah engkau mengatakan kepada keduanya perkataan 'ah' dan janganlah engkau membentak keduanya, dan ucapkanlah kepada keduanya perkataan yang baik" (Departemen Agama RI, 2013:284). d) Qawlan Ma'rufan (perkataan yang baik, pantas)

Ungkapan qawlan ma'rufan, dapat diartikan dengan ungkapan atau ucapan yang pantas dan baik. Pantas di sini juga bisa diartikan sebagai kata-kata yang terhormat, sedangkan baik diartikan sebagai kata-kata yang sopan.

Qawlan Ma'rufan juga bermakna pembicaraan yang bermanfaat dan menimbulkan kebaikan. Sebagai muslim yang beriman, perkataan kita harus terjaga dari perkataan yang sia-sia, apapun yang kita ucapkan harus selalu mengandung nasehat, menyejukkan hati bagi orang yang mendengarnya. Jangan sampai kita hanya mencari-cari kejelekan orang lain, yang hanya bisa mengkritik atau mencari kesalahan orang lain, memfitnah dan menghasut.

Ungkapan qawlan ma'rufan terungkap dalam Q.S. An-Nisaa: 8

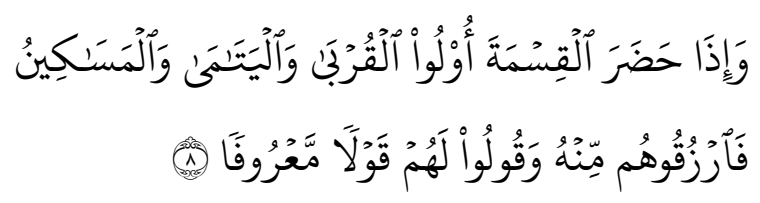

Artinya: "Dan apabila sewaktu pembagian itu hadir beberapa kerabat, anak-anak yatim dan orang-orang miskin, maka berilah mereka dari harta itu (sekedarnya) dan ucapkanlah kepada mereka perkataan yang baik" (Departemen Agama RI, 2013:78).

Ayat tersebut menjelaskan bahwa, qawlan ma'rufan adalah perkataan yang baik. Qawlan ma'rufan berarti pembicaraan yang bermanfaat, memberikan pengetahuan, mencerahkan pemikiran, menunjukan pemecahan terhadap kesulitan kepada orang lemah, jika tidak dapat membantu secara material, setidaknya dapat membantu secara psikologi. 
e) Qawlan Layyina (lemah lembut)

Qawlan Layyina berarti pembicaraan yang lemah-lembut, dengan suara yang enak didengar, dan penuh keramahan, sehingga dapat menyentuh hati. Rasullulah selalu bertutur kata dengan lemah lembut, hingga setiap kata yang beliau ucapkan sangat menyentuh hati siapapun yang mendengarnya.

Perilaku untuk berlaku lemah lembut tersebut tergambar dalam Q.S. Thaa-haa: 44

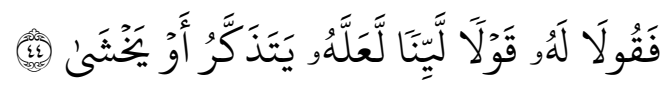

Artinya: "Maka berbicaralah kamu berdua kepadanya (Fir'aun) dengan katakata yang lemah lembut, mudah-mudahan dia sadar atau takut" (Departemen Agama RI, 2013:314).

Dengan demikian, interaksi aktif dari qawlan layyina adalah komunikasi yang ditujukan pada dua karakter komunikan. Pertama, adalah pada komunikan tingkat penguasa dengan perkataan yang lemah lembut menghindarkan atau menimbulkan sifat konfrontatif. Kedua, komunikan pada tataran budayanya yang masih rendah. Sikap dengan qawlan layyina akan berimbas pada sikap simpati dan sebaliknya akan menghindarkan atu menimbulkan sikap antipati.

f) Qawlan Maisura (mudah diterima).

Secara terminologi qawlan maisura berarti "mudah". Lebih lanjut komunikasi islami dengan menggunakan qawlan maisura dapat diartikan bahwa dalam menyampaikan pesan (content), komunikator harus menggunakan bahasa yang ringan, sederhana, atau mudah diterima oleh komunikan secara spontan tanpa harus melalui pemikiran berat.

Perkataan qawlan maisura terekam pada Q.S. Al-Israa: 28

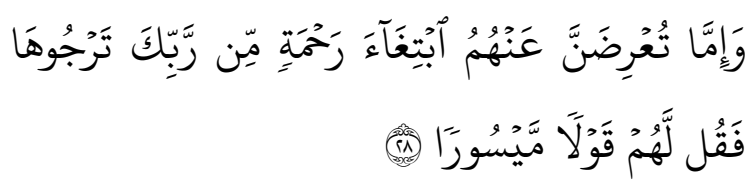

Artinya: "Dan jika engkau berpaling dari mereka untuk memperoleh rahmat dari Tuhanmu yang engkau harapkan, maka katakanlah kepada mereka ucapan yang lemah lembut" (Departemen Agama RI, 2013:285).

Maksud dari ayat di atas, apabila kamu tidak dapat melaksanakan perintah Allah Swt, maka katakanlah kepada mereka perkataan yang baik agar mereka tidak kecewa lantaran mereka belum mendapat bantuan dari kamu. Oleh karena itu, kamu dapat memberikan kepada mereka hak-hak mereka.

\section{ANALISIS PROSES PELIPUTAN BERITA "LINTAS PAGI"}

\section{Agenda Setting}

Langkah pertama yang dilakukan bidang pemberitaan RRI Semarang sebelum meliput berita "Lintas Pagi" adalah melakukan rapat agenda setting. Untuk melakukan liputan berita terduga, ada beberapa hal yang perlu mendapat perhatian, yakni sebagai berikut (Yunus, 2010:56):

4. Mempersiapkan rencana liputan yang optimal. Topik berita perlu digali secara produktif, kreatif dan kritis.

5. Liputan harus dapat dipertanggung jawabkan dan transparan.

6. Memiliki catatan liputan yang jelas, akurat dan kontekstual.

Selama penulis melakukan pengamatan, ketiga hal tersebut sudah dilakukan saat merencanakan peliputan. Ketika rapat agenda setting, pemimpin rapat berusaha menggali peristiwa yang sedang hangat terjadi di masyarakat untuk di angkat menjadi sebuah berita. Ini 
dibuktikan dengan, saat rapat agenda setting berlangsung, pemimpin rapat yang dalam hal ini adalah kepala seksi, membuat line topik berita berdasarkan apa yang sedang terjadi di masyarakat. Dari banyaknya peristiwa yang terjadi hanya peristiwa yang memiliki nilai berita (faktual, aktual, dan menarik) yang tinggi yang akan di liput menjadi berita "Lintas Pagi". Kriteria kelayakan yang menjadi tolok ukur suatu fakta atau peristiwa menjadi berita adalah : berita harus penting, berita harus aktual, dan berita harus unik (Yunus, 2010:73).

Selain menentukan peristiwa yang akan diliput, penentuan narasumber juga di bahas di dalam rapat agenda setting. Dalam menentukan narasumber, pemimpin rapat juga tidak sembarangan. Hal ini dilakukan agar hasil berita dan wawancara yang diperoleh dapat dipertanggung jawabkan. Namun apabila narasumber yang telah di tentukan, tidak dapat melakukan wawancara dengan reporter. Reporter harus mencari narasumber pengganti yang juga relevan dan bisa di pertanggung jawabkan pernyataannya.

Jika di tinjau dari perspektif komunikasi islami, ketika melakukan rapat ageda setting tim pemberitaan RRI Semarang berusaha memenuhi salah satu prinsip komunikasi islami, yakni Qawlan Sadidan. Qawlan Sadidan yang berarti pembicaran, ucapan, atau perkataan yang benar dari segi substansi (materi, isi, pesan). Apabila peristiwa yang diangkat menjadi sebuah berita memang faktual dan benar terjadi, maka secara otomatis pesan yang terkandung di dalam berita juga fakta yang terjadi di masyarakat. Pembicaraa di sini dapat di maksudkan sebagai pesan yang terkandung di dalam berita "Lintas Pagi" memang benar adanya dan fakta.
Dari segi substansi, komunikator harus menginformasikan atau menyampaikan kebenaran, faktual, hal yang benar saja, jujur, tidak berbohong, juga tidak merekayasa atau memanipulasi fakta. Dari segi redaksi, komunikator harus menggunakan kata-kata yang baik dan benar, baku, dan sesuai kadiah bahasa yang berlaku.

Hal ini sesuai dengan Q.S. Al Baqarah ayat 83 :

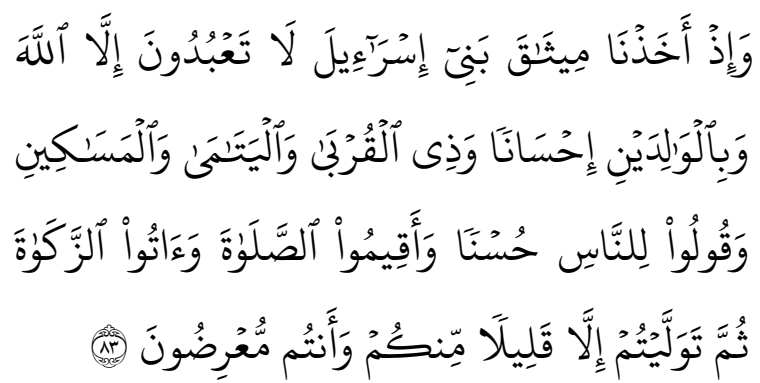

Artinya "dan (ingatlah), ketika Kami mengambil janji dari Bani Israil (yaitu): janganlah kamu menyembah selain Allah, dan berbuat kebaikanlah kepada ibu bapa, kaum kerabat, anak-anak yatim, dan orang-orang miskin, serta ucapkanlah kata-kata yang baik kepada manusia, dirikanlah shalat dan tunaikanlah zakat. kemudian kamu tidak memenuhi janji itu, kecuali sebahagian kecil daripada kamu, dan kamu selalu berpaling." (Departemen Agama RI, 2013:12).

Seluruh tim Seksi Liputan Berita dan Dokumentasi harus menghadiri rapat agenda setting. Baik kepala seksi, desk editor dan reporter. Aturan ini dibuat untuk meminimalisir kesalahan yang mungkin terjadi selama proses peliputan berita "Lintas Pagi", juga untuk menyamakan persepsi di antara kepala seksi, desk editor, dan reporter.

Adanya kewajiban mengikuti rapat agenda setting, jika di tinjau dari perspektif komunikasi islami, bahwa bidang pemberitaan RRI Semarang 
mempraktekkan prinsip komunikasi islami. Penerapan prinsip komunikasi islami dapat dilihat dari menjunjung tinggi nilai-nilai etika dalam menyampaikan pesan.

\section{Reporter}

Setelah mengikuti rapat agenda setting, reporter melakukan penghimpunan data yang akan digunakan sebagai bekal untuk wawancara dengan narasumber dan menulis berita. Menghimpun data termasuk bagian dari orientasi narasumber dan orientasi topik berita. Hal ini dilakukan agar ketika melakukan wawancara, reporter sudah mengetahui nama dan jabatan narasumber serta saat wawancara reporter telah siap dengan bahan yang dimiliki, sehingga saat berjalannya wawancara dapat berjalan sesuai dengan harapan (Yunus, 2010:60-61).

Selepas menghimpun data, reporter mendatangi narasumber untuk wawancara. Wawancara yang dilakukan reporter adalah untuk tujuan faktual, yaitu mencari, menggali dan mengumpulkan fakta-fakta yang mendukung berita (Yunus 2010:62). Ditinjau dari perspektif komunikasi islami, tujuan reporter melakukan wawancara merupakan bagian dari prinsip komunikasi islami yaitu Qawlan Sadidan. Reporter benar-benar melakukan konfirmasi dan menggali kebenaran kabar yang berkembang di masyarakat untuk dapat menulis berita dengan benar.

Dalam melakukan wawancara, jika reporter melakukan wawancara dengan tulus dan narasumber tahu bahwa reporter tersebut mempunyai rasa empati, maka narasumber akan banyak berbicara. Wawancara yang baik adalah ketika reporter bisa memungkinkan narasumber untuk mengatakan apa yang sebenarnya terjadi.
Bersikap sopan santun dan ramah selama melakukan wawancara juga di ajarkan di dalam agama Islam. Baik kepada orang yang lebih tua maupun yang lebih muda. Agar orang lain tidak merasa tersakiti atas perbuatan dan ucapan kita.

Sebagai media penyampai informasi kepada masyarakat luas, hendaknya RRI Semarang memang selalu memberikan informasi yang faktual, benar adanya, dan tidak memberikan berita dan informasi yang membingungkan masyarakat luas. Anjuran memberikan informasi yang benar sehingga nantinya tidak menjurus kepada ghibah terdapat pada firman Allah Q.S. AlHujurat ayat 12 :

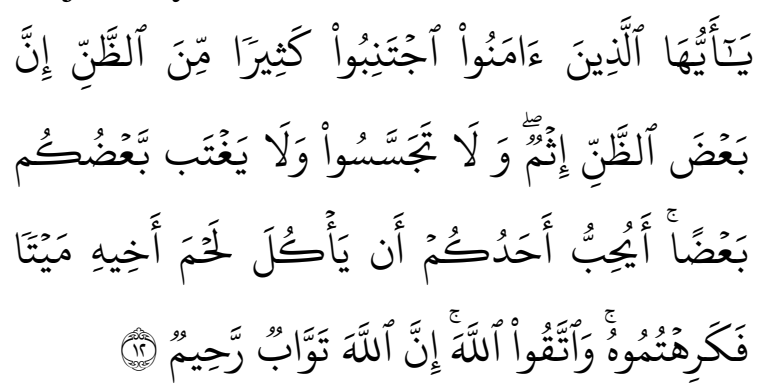

Artinya: "Wahai orang-orang yang beriman! Jauhilah banyak dari prasangka, sesungguhnya sebagian prasangka itu dosa, dan janganlah kamu mencari-cari kesalahan orang lain, dan janganlah ada diantara kamu yang menggunjing sebagian yang lain. Apakah ada diantara kamu yang suka memakan daging saudaranya yang sudah mati? Tentu kamu merasa jijik. Dan bertakwalah kepada Allah, sungguh Allah Maha Penerima tobat, Maha Penyayang." (Departemen Agama RI, 2013:517).

Selain telah di atur di dalam AlQur'an, kewajiban menyampaikan berita yang faktual dan benar juga telah di jelaskan di dalam Peraturan Pemerintah Republik Indonesia Nomor 11 Tahun 2005 Tentang Penyelenggaraan Penyiaran Lembaga Penyiaran Publik pasal 18 ayat 4(a) tentang penyelenggaraan penyiaran 
bagian isi siaran menjelaskan bahwa isi siaran RRI, TVRI, dan Lembaga Penyiaran Publik Lokal dilarang : Pertama bersifat fitnah, menghasut, menyesatkan dan/atau bohong. Kedua menonjolkan unsur kekerasan, cabul, perjudian, penyalahgunaan narkotika dan obat terlarang. Ketiga mempertentangkan suku, agama, ras dan antar golongan.

Selesai melakukan wawancara, reporter kembali ke kantor untuk menulis berita yang telah diperolehnya. Menulis berita untuk radio, berbeda dengan menulis berita untuk media cetak atau televisi. Karena radio adalah media komunikasi auditif (dengar) sehingga berita yang di tulis harus singkat, padat dan jelas. Saat menulis berita, reporter menerapkan lima azaz penulisan, yaitu it's spoken (diucapkan), it's immediate (sekarang, langsung), it's person to person (antar orang), it's heard only once (terdengar hanya satu kali), it's sound only (hanya bunyi) (Oramahi, 2003:37).

Salah satu karakteristik radio adalah selintas dan mengandung gangguan maka reporter juga menerapkan angka-angka yang dibulatkan, kalimat-kalimat yang ringkas, susunan kalimat yang akurat dan bergaya obrolan, serta kata-kata yang umum dan lazim digunakan (Effendy, 1990:87).

Dilihat dari perspektif komunikasi islami cara reporter menulis berita maka, reporter menerapkan beberapa prinsip komunikasi islami. Prinsip yang digunakan yaitu :

Pertama, Qawlan Sadidan. Qawlan Sadidan artinya perkataan yang benar. Perkataan yang benar dapat diwujudkan dengan manjaga lisan. Jika dikaitkan dengan komunikasi, seorang komunikator dalam menyampaikan pesannya, berupa pesan yang jujur dan tidak melakukan kebohongan.

Sebelum menulis berita "Lintas Pagi" reporter sudah melakukan yang namanya penghimpunan data dan wawancara. Kedua langkah tersebut dilakukan untuk memastikan berita yang ditulis serta disiarkan berupa pesan yang jujur dan tidak mengandung kebohongan.

Allah memerintahkan qawlan sadidan dalam FirmanNya Q.S. Al-Ahzaab ayat 70 :

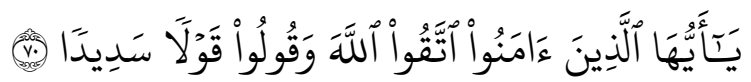

Artinya: "Wahai orang-orang yang beriman! Bertakwalah kamu kepada Allah dan ucapkanlah perkataan yang benar" (Departemen Agama RI, 2013:467).

Didalam Al-Qur'an Allah SWT memerintahkan qawlan sadidan setelah bertakwa. Takwa sendiri artinya adalah kepercayaan akan adanya Allah, membenarkan dan takut akan Allah (id.m.wikipedia.org diakses pada 26 Januari 2018). Artinya adalah bahwa apabila seorang reporter percaya akan adanya Allah SWT maka, harus mengucapkan perkataan yang benar.

Al-Qur'an menyatakan bahwa berbicara yang benar, adalah prasyarat untuk kebenaran (kebaikan, kemaslahatan) amal. Bila ingin memperbaiki masyarakat, maka harus menyebarkan pesan yang benar. Dengan kata lain, masyarakat menjadi rusak bila isi pesan komunikasi tidak benar.

Kedua, Qawlan Baligha. Qawlan baligha disini diartikan komunikasi dengan menggunakan kata-kata yang efektif, tepat sasaran, komunikatif, dan mudah dimengerti. Hal ini sangat erat kaitannya dengan pemberitaan di radio yang memang di batasi oleh waktu, sehingga kalimat yang mengudara harus efektif, mudah dimengerti 
dalam sekali dengar dan langsung kepada pokok permasalahan.

Ungkapan Qawlan Baligha terlihat dalam Q.S. Ibrahim ayat 4 :

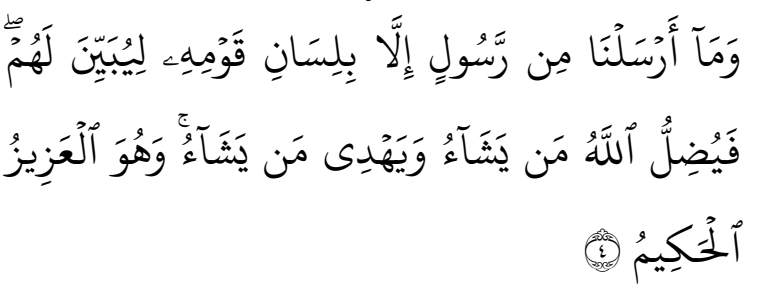

Artinya : "dan Kami tidak mengutus seorang rasulpun, melainkan dengan bahasa kaumnya, supaya ia dapat memberi penjelasan dengan terang kepada mereka. Maka Allah menyesatkan siapa yang Dia kehendaki, dan memberi petunjuk kepada siapa yang Dia kehendaki. dan Dia-lah Tuhan yang Maha Kuasa lagi Maha Bijaksana." (Departemen Agama RI, 2013:255).

Agar komunikasi yang dilakukan reporter dapat tepat mengenai sasaran pendengarnya, maka, gaya bicara dan pesan yang disampaikan hendak harus disesuaikan dengan kadar intelektualitas pendengar dan menggunakan bahasa yang dimengerti oleh mereka.

Ketiga, Qawlan Karima. Qawlan Karima artinya adalah perkataan yang mulia, yang di barengi dengan rasa hormat, enak di dengar, lemah lembut dan bertata krama. Walaupun segmentasi pendengar berita "Lintas Pagi" usia 15 tahun ke atas, namun kebanyakan yang mendengarkan berita "Lintas Pagi" adalah orang dengan usia diatas 25 tahun. Maka dari itu, reporter dalam menulis berita menggunakan bahasa yang sopan, dan tidak menyinggung pihak manapun. Agar siapapun yang mendengarkan berita "Lintas Pagi" tidak merasa tersinggung.

Ungkapan Qawlan Karima terdapat dalam Q.S. Al-Isra' ayat 23 :

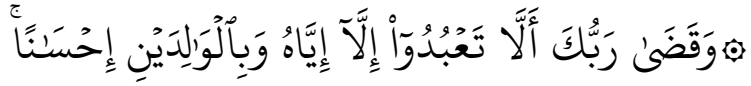

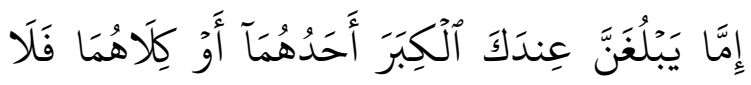

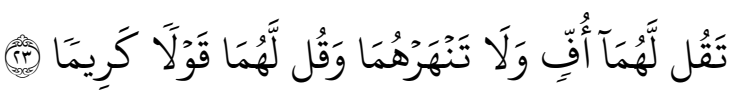
Artinya : "dan Tuhanmu telah memerintahkan supaya kamu jangan menyembah selain Dia dan hendaklah kamu berbuat baik pada ibu bapakmu dengan sebaik-baiknya. jika salah seorang di antara keduanya atau Kedua-duanya sampai berumur lanjut dalam pemeliharaanmu, Maka sekali-kali janganlah kamu mengatakan kepada keduanya Perkataan "ah" dan janganlah kamu membentak mereka dan ucapkanlah kepada mereka Perkataan yang mulia." (Departemen Agama RI, 2013:284).

Dalam konteks jurnalistik dan penyiaran, Qawlan Karima bermakna mengunakan kata-kata yang santun, tidak kasar, tidak vulgar, dan menghindari "bad taste”, seperti jijik, muak, ngeri, dan sadis. Hal-hal ini harus di hindari oleh reporter berita "Lintas Pagi" ketika menulis berita.

Keempat, Qawlan Ma'rufan. Qawlan Ma'rufan dapat diartikan pembicaraan yang bermanfaat dan menimbulkan kebaikan. Di tinjau dalam dunia komunikasi bisa diartikan sebagai pesan yang bermanfaat. Sesuai dengan tujuan adanya berita "Lintas Pagi" yaitu untuk mendorong pihak terkait dalam hal ini yang dimaksud adalah pemerintah untuk melakukan sesuatu terhadap masalah yang sedang di hadapi masyarakat serta mengedukasi masyarakat. Sehingga berita yang disiarkan dalam program acara "Lintas Pagi" dapat bermanfaat untuk pendengarnya.

Ungkapan Qawlan Ma'rufan terdapat pada Q.S Al Baqarah ayat 23 : 


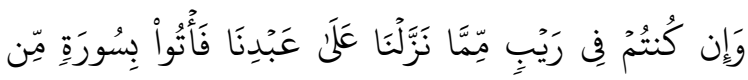

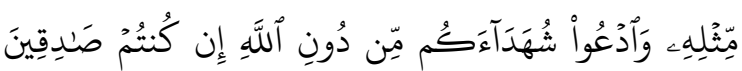

Artinya : "Perkataan yang baik dan pemberian maaf lebih baik dari sedekah yang diiringi dengan sesuatu yang menyakitkan (perasaan si penerima). Allah Maha Kaya lagi Maha Penyantun." (Departemen Agama RI, 2013:44).

RRI adalah satu-satunya stasiun radio yang dimiliki oleh Negara Kesatuan Republik Indonesia (NKRI). RRI merupakan radio yang mempunyai posisi yang strategis, sebab realitasnya RRI masih merupakan satu-satunya radio jaringan nasional dan mampu menjangkau hampir seluruh wilayah Indonesia.

RRI juga sangat berperan membantu menjaga stabilitas NKRI dengan memberikan informasi yang mendidik dan cerdas mengenai tema-tema kebangsaan, nasionalisme, pendidikan, dan kebudayaan. Maka dari itu RRI Semarang melalui program acara berita "Lintas Pagi", menyiarkan berita yang bermanfaat bagi setiap pendengarnya.

Kelima, Qawlan Layyina. Qawlan Layyina berarti pembicaraan yang lemahlembut, dengan suara yang enak didengar, dan penuh keramahan, sehingga dapat menyentuh hati. Salah satu karakteristik radio adalah akrab, dengan menerapkan kalimat-kalimat yang enak di dengar, penuh keramahan saat menulis berita membuat apa yang disampaikan reporter ketika membacakan berita dapat langsung mudah di tangkap pendengar.

Ungkapan Qawlan Layyina terdapat dalam Q.S Taha ayat 44 :

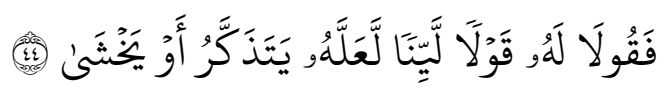

Artinya : "Maka berbicaralah kamu berdua kepadanya (Fir'aun) dengan katakata yang lemah lembut, Mudah-mudahan ia ingat atau takut." (Departemen Agama RI, 2013:314).

Walaupun feedback dalam berita "Lintas Pagi" tidak berlangsung saat berita disiarkan, namun dengan menyiarkan berita menggunakan bahasa yang lemah-lembut, suara yang enak didengar dan penuh keramahan akan membuat pendengar betah mendengarkan berita "Lintas Pagi" dari awal sampai akhir.

Islam mengajarkan agar menggunakan komunikasi yang lemah lembut kepada siapa pun. Dalam lingkungan apapun, komunikator sebaiknya berkomunikasi pada komunikan dengan cara lemah lembut, jauh dari pemaksaan dan permusuhan. Dengan menggunakan komunikasi yang lemah lembut, selain ada perasaan bersahabat (akrab) yang menyusup ke dalam hati komunikan, ia juga berusaha menjadi pendengar yang baik.

Keenam, Qawlan Maisura. Komunikasi islami dengan menggunakan Qawlan Maisura dapat diartikan bahwa dalam menyampaikan pesan (content), komunikator harus menggunakan bahasa yang ringan, sederhana, atau mudah diterima oleh komunikan secara spontan tanpa harus melalui pemikiran berat. Berita "Lintas Pagi" adalah berita radio yang dinikmati menggunakan indera pendengaran (telinga), dan telinga hanya dapat menyimak kata demi kata yang terangkum dalam satu kalimat. Berbeda dengan mata yang dapat menangkap satu kalimat dengan utuh secara seketika. Hal ini yang menjadi acuan reporter untuk menggunakan bahasa yang sederhana dan mudah di terima ketika menulis berita. 
Ungkapan Qawlan Maisura terdapat dalam Q.S Al Isra ayat 28 :

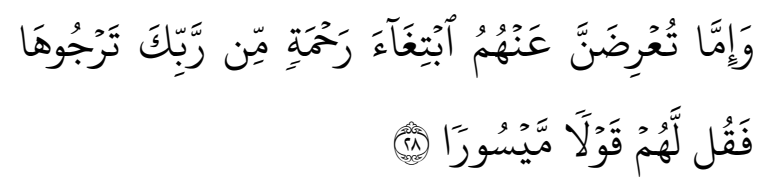

Artinya : "dan jika kamu berpaling dari mereka untuk memperoleh rahmat dari Tuhanmu yang kamu harapkan, Maka Katakanlah kepada mereka Ucapan yang pantas." (Departemen Agama RI, 2013:314)

Dalam komunikasi, baik lisan maupun tulisan, dianjurkan untuk mempergunakan bahasa yang mudah, ringkas, dan tepat sehingga mudah dicerna dan dimengerti. Dalam Al-Qur'an ditemukan istilah qawlan maisura yang merupakan salah satu tuntunan untuk melakukan komunikasi dengan mempergunakan bahasa yang mudah dimengerti dan melegakan perasaan (Djamarah,2004:110).

Saat menulis reporter berita "Lintas Pagi" menggunakan pola penulisan berita adikasimba, yakni pola penulisan yang menekankan pada cara menulis berita yang bersifat baku, dengan menyajikan aspek apa, dimana, kapan, siapa, mengapa, dan bagaimana (Yunus, 2010:67). Tetapi, tidak semua unsur $5 \mathrm{~W} 1 \mathrm{H}$ (what, when, where, why, who, how) di terapkan dalam satu buah berita. Biasanya reporter menghilangkan unsur kapan dan dimana (tempat) dilakukannya wawancara. Menurut pengamatan penulis, apa yang dilakukan reporter tidak melanggar prinsip komunikasi islami. Sebab jika di lihat dari perspektif komunikasi islami, reporter tetap menuangkan apa yang terjadi di lapangan dengan bahasa yang sopan, lemah lembut, mudah di mengerti, walaupun menghilangkan unsur kapan dan dimana. Menghilangkan unsur kapan dan dimana dilaksanakannya wawancara, tidak membuat nilai suatu berita berubah.

Saat reporter menulis berita, idealnya reporter sembari ikut mengucapkan apa yang sedang ditulisnya. Hal ini dilakukan agar berita yang sedang ditulis dapat mudah dipahami dan tidak menimbulkan makna ganda ketika didengarkan. Sebagaimana yang dikatakan Oramahi (2003) bahwa menulis untuk radio adalah menulis untuk telinga. Tulislah berita yang ingin disiarkan sambil berbicara (membacanya). Karena batas waktu yang amat ketat, apa yang hendak disiarkan melalui radio haruslah tertulis. Kendati demikian, gunakan kalimat dengan ragam lisan (Oramahi, 2003:36).

Reporter berita radio harus bisa menulis berita sambil membacanya, sehingga reporter dapat langsung merasakan dan menghayati, bahwa seperti itulah bunyi berita tersebut apabila disiarkan oleh penyiar dan di dengar oleh pendengar. Ketika berita yang ditulisnya dirasa ambigu atau malah membingungkan, maka reporter akan segera merasakannya.

Setelah selesai menulis seorang reporter harus melakukan controlling /pengawasan sebelum berita yang ditulisnya disimpan kedalam folder yang nantinya akan disunting oleh desk editor. Apabila reporter merasa hasil liputannya kurang memuaskan, maka harus diperbaiki. Hal ini merupakan bagian dari check and recheck. Dengan demikian, ketika suatu karya jurnalistik sampai ke tangan desk editor, maka karya itu sudah melalui kontrol awal. Kontrol selanjutnya dilakukan oleh deks editor.

Islam telah menyerukan agar senantiasa bersikap hati-hati dalam segala urusan, melakukan pengamatan dengan seksama dan penuh pertimbangan sebelum memutuskan suatu perkara. Melakukan controlling terhadap berita yang telah di 
liput, merupakan suatu sikap berhati-hati yang dilakukan reporter untuk menghindari kesalahan.

\section{Desk Editor}

Desk editor akan mulai bekerja mengedit atau menyunting berita hasil liputan reporter. Di sini berita akan memasuki proses controlling akhir. Bagian ini menjadi sangat penting sekali, sebab desk editor adalah pengawas terakhir dari segala hasil karya jurnalistik reporter sebelum di udarakan. Kesalahan melakukan penyuntingan dapat berakibat fatal.

Dari segi proses, kegiatan penyuntingan berita yang dilakukan desk editor melalui dua tahap yaitu : penyuntingan redaksional yang mengacu pada penekanan aspek kelogisan berita, kemudahan pemahaman dan kejelasan makna, serta yang kedua yaitu penyuntingan substansial yang mengacu pada keakuratan data dan kebenaran fakta yang disajikan dalam berita sehingga isi berita menjadi lebih mudah dipahami (Yunus, 2010:88).

Desk editor menyunting berita yang berbentuk naskah dan berita yang berbentuk audio. Desk editor memastikan bahwa berita yang akan di dengar pendengar tidak ambigu serta dapat langsung di pahami dalam sekali dengar.

Saat menyunting desk editor secara tidak langsung mengecek, apakah semua prinsip komunikasi islami, yaitu qawlan sadidan, qawlan baligha, qawlan karima, qawlan ma'rufan, qawlan layyina, dan qawlan maisura dilaksanakan dengan baik dan benar.

Sebab prinsip komunikasi islami penulis rasa cocok apabila dijadikan panduan dalam proses peliputan berita. Meski berita "Lintas Pagi" bukan berita religi. Tetapi prinsip yang mengatakan untuk memberikan pesan yang baik, benar, lemah lembut, menggunakan bahasa yang lazim, bermanfaat

Apabila di rasa tidak ada kesalahan, desk editor akan mencetak berita yang berbentuk naskah serta menyatukan berita yang berbentuk audio yang di buat oleh masing-masing reporter yang bertugas untuk di serahkan ke bagian penyiaran.

Suara merupakan modal utama radio sebagai media komunikasi. Media radio yang hanya bermodalkan suara, berusaha memvisualisasikan suatu peristiwa agar dapat menciptakan imajinasi kejadian yang sebenarnya dalam benak pendengar. Menciptakan imajinasi kepada pendengar tidak sebatas dalam bidang artistik, tetapi juga berlaku dalam bidang jurnalistik, para reporter berusaha memvisualisasikan suatu peristiwa dengan mengandalkan kekuatan suara, melalui sisipan suara narasumber.

Menciptakan ruang imajinasi kepada pendengar harus dilakukan dengan berhatihati. Kesalahan dalam menyiarkan berita dapat berakibat fatal. Karena selain sulitnya meralat berita di radio hal itu juga bisa membuat masyarakat keliru dalam memahami berita. Sehingga apa yang diharapkan dari munculnya berita tersebut tidak berjalan lancar.

Maka dari itu, prinsip komunikasi islami cocok jika diterapkan di dalam proses peliputan berita "Lintas Pagi". Apalagi berita "Lintas Pagi" merupakan icon RRI Semarang. Meskipun berita "Lintas Pagi" bukan berita religi.

Dalam perspektif komunikasi islami, proses penyampaian pesan dari komunikator kepada komunikan harus disampaikan secara jujur dan sesuai dengan prinsip-prinsip yang terkandung dalam nilai-nilai Al-Quran dan Hadits Nabi, karena yang demikian dianggap bagian dari ibadah. Maka dalam penerapannya prinsip 
komunikasi islami berlangsung antara manusia sekaligus dengan Tuhannya.

Secara aksioma dapat dikatakan, bahwa semua komunikasi antara manusia (human communication) itu adalah ibadah. Jika dilakukan dengan niat berbuat baik dan cara melakukannya juga baik sesuai dengan kriteria dari sistem sosial yang berlaku. Misalnya di Indonesia sesuai dengan Pancasila sebagai acuan baku dan tidak melanggar hukum (Muis, 2001:186).

Mengenai sistem komunikasi sosial dan sistem media massa, menurut agama Islam, ada yang disebut kebebasan komunikasi atau kebebasan media massa yang bertanggung jawab. Bertanggung jawab disini yang dimaksud adalah bertanggung jawab terhadap Allah SWT. Didalam TAP MPR No. XXXII/1966 dan UU Pers ditentukan, bahwa kebebasan pers harus dibatasi dengan rasa tanggung jawab kepada Tuhan Yang Maha Esa (Muis, 2001:181). Tanggung jawab bagi kebebasan pers menurut Islam, tidak berbeda dengan apa yang ada dalam hukum pidana media massa atau hukum pidana komunikasi dan Kode Etik Jurnalistik (Muis, 2001:182).

Sanksi atas pelanggaran terhadap komunikasi islami berlaku sampai di Akhirat. Ada hukuman akhirat dan hukuman di alam kubur atau alam barzah. Para pelanggar terancam sanski yang pedih di Akhirat (neraka). Banyak ayat didalam Al-Qur'an yang telah menjelaskan hal tersebut baik secra eksplisit maupun implisit. Di samping hukuman, ada yang namanya ganjaran atau pahala yang disediakan untuk komunikator yang berhasil menaati prinsip-prinsip komunikasi islami.

Reporter RRI Semarang semuanya beragama Islam, sehingga seharusnya reporter memiliki ada beban tersendiri jika mereka menyiarkan berita yang tidak sesuai dengan fakta. Mereka akan mendapat sanksi sosial dari para pendengar setia berita "Lintas Pagi" dan sanksi di Akhirat.

Di dalam Hadits Nabi disebutkan "Katakanlah apa yang benar sekalipun pahit". Dapat ditafsirkan, bahwa kebebasan menyampaikan infromasi dengan lisan dan tulisan dapat menimbulkan dampak yang luas bagi masyarakat terutama jika menyampaikan pesan menggunakan media massa. Media massa cepat mencapai khalayak massal (mass audience) yang jumlahnya relatif tidak terbatas dan bersifat heterogen (Muis, 2001:75).

Sehingga seluruh eleman bidang pemberitaan, mulai dari kepala seksi, reporter dan desk editor memiliki tanggung jawab yang besar dalam menyiarkan berita khususnya di media massa yang bersifat auditif.

\section{KESIMPULAN}

Setelah menguraikan tentang pembahasan dan analisis sesuai dengan pokok permasalahan yang diangkat dalam skripsi ini, maka penulis menarik kesimpulan, bahwa proses peliputan berita "Lintas Pagi" RRI Semarang sudah memenuhi konsep yang ditentukan dalam perspektif komunikasi islami.

Proses peliputan berita "Lintas Pagi" di mulai dari rapat agenda setting, menghimpun data, melakukan wawancara, menulis berita dan mengedit berita. Rapat agenda setting adalah rapat yang dilakukan setiap hari pada pukul 08.00 WIB dengan tujuan untuk menentukan berita apa yang akan disiarkan hari esok dan menyamakan pikiran tentang berita yang akan disiarkan, sehingga terjadi kesepemahaman antara kepala seksi, desk editor dan reporter. Reporter yang bekerja meliput berita "Lintas Pagi" melakukan tugasnya dari 
mengikuti rapat agenda setting, menggali data untuk berita, mendatangi narasumber serta menulis berita. Setelah reporter menulis berita, maka desk editor akan mengoreksi isi berita yang telah di tulis, dan mendengarkan berita secara audio untuk mengoreksi keterpaduan berita dari segi pemenggalan kalimat ketika reporter membacakan berita.

Dilihat dari proses peliputan berita "Lintas Pagi", keseluruhan proses secara tidak langsung menerapkan prinsip komunikasi islami, yakni qawlan sadidan, qawlan baligha, qawlan karima, qawlan ma'rufan, qawlan layyina, dan qawlan maisura.

Berita "Lintas Pagi" memang bukan program berita religi atau islami dan RRI Semarang bukan radio dakwah. Namun tim pemberitaan RRI Semarang dalam melakukan peliputan secara tidak langsung menggunakan prinsip komunikasi islami.

\section{DAFTAR PUSTAKA}

Departemen Agama Republik Indonesia, Al-Qur'an Terjemah, (Bekasi: Cipta Bagus Segara, 2013)

Djamarah, Syaiful Bahri, Pola Komunikasi Keluarga Orang Tua dan Anak Dalam Keluarga, (Jakarta: PT Rineka Cipta, 2004)

Effendy, Onong Uchjana, Radio Siaran Teori dan Prakiter, (Bandung: CV. Mandar Maju, 1990)

Oramahi, Hasan Asy'ari, Menulis Untuk

Telinga, (Jakarta: PT. Gramedia Pustaka Utama, 2003)

Romli, Asep Syamsul M., Jurnalistik Praktis untuk Pemula edisi revisi, (Bandung: PT. Remaja Rosdakarya, 2005)

Sumadiria, Haris, Jurnalistik Indonesia Menulis Berita dan Feature Panduan Praktis Jurnalis Profesional,
(Bandung: Simbiosa Rekatama Media, 2014)

Tamburaka, Apriadi, Agenda Setting Media Massa, (Jakarta: PT. Rajagrafindo Persada, 2013)

Yunus, Syarifudin, Jurnalistik Terapan, (Bogor: Ghalia Indonesia, 2010) 